Article

\title{
Sex, Drug, and HIV/AIDS: The Drug Career of an Urban Chinese Woman
}

\author{
Xiying Wang ${ }^{1}$ and Liu Liu ${ }^{2, *}$ \\ ${ }^{1}$ Institute for Education Theories, Faculty of Education, Beijing Normal University, 100875 Beijing, China; \\ E-Mail: xiyingw@bnu.edu.cn \\ ${ }^{2}$ School of Social and Behavioral Sciences, Nanjing University, 210023 Nanjing, China; E-Mail: liuliu@nju.edu.cn \\ * Corresponding author
}

Submitted: 13 November 2019 | Accepted: 25 February 2020 | Published: 28 April 2020

\begin{abstract}
This case study is based on the life history of an urban Chinese woman, Lydia, who has become an AIDS patient through injecting heroin use. Adopting theories of drug career and biopolitics, this study depicts Lydia's drug-centered life. From the perspective of a drug career, this article vividly illustrates her experience of drug initiation, escalation, maintenance, and finally achievement of abstinence. In addition, this study also shows how drug use has penetrated all dimensions of Lydia's life including intimate relationships, financial arrangements, and compulsory drug treatment; in the end, contracting HIV was when she finally hit rock bottom and worked to get rid of her heroin dependence. From the perspective of biopolitics, this article focuses on the institutional and social structure transformation that is reflected by Lydia's personal experience, especially the social service, treatment, and intervention programs provided for her during an era of increasingly growing drug use and HIV-infected population.
\end{abstract}

\section{Keywords}

addiction; biopolitics; case study; China; drug career; HIV/AIDS; substance abuse

\section{Issue}

This article is part of the issue "Left Behind? Women's Status in Contemporary China" edited by Robert Walker (Beijing Normal University, China) and Jane Millar (University of Bath, UK).

(C) 2020 by the authors; licensee Cogitatio (Lisbon, Portugal). This article is licensed under a Creative Commons Attribution 4.0 International License (CC BY).

\section{Introduction: Lydia's Story}

In the end of 2012 to early 2013, the first author had the privilege to work with a local NGO in Beijing, China, for HIV/AIDS carriers' rights and provided a 12-week support group for 11 women living with HIV/AIDS. The support group met once a week on Saturday afternoons for three hours, discussing different kinds of experiences and feelings in these women's lives, including illness and healthseeking behaviors, families and marriages, love and dating, and sexuality and reproduction. Afterwards, the first author interviewed each of the group participants for 2-8 hours, and Lydia was one of them. Her case stands out because of its complexity, which involves not only drug consumption and HIV/AIDS infection, but also various aspects of an urban woman's life in rapidly developing China.
Lydia was born in 1978, the year of economic reform and opening up. She grew up in a Beijing hutong (ally) and enjoyed the privilege of being a "pure and proper" Beijinger. Lydia has a nice voice, and her parents invested in her talent and sent her to learn singing and piano when she was a child. Lydia did well in school and her talent of singing secured her an early admission to the most prestigious music institute in China at the age of 17 . It seemed that a bright future of being a musician was awaiting this young, talented girl. However, after 20 years, Lydia is now single, job-less, overweight, living with her parents, a recovered drug-dependent and AIDS patient. What happened? How did Lydia become a drug user and later became infected with HIV/AIDS?

This study tries to analyze the path Lydia's life took. It is invaluable since it reveals an urban Chinese woman's subjective experience that connects sex, drug, 
and HIV/AIDS. A life history approach was adopted since it allows Lydia to present her story in her own voice. This story is what "a person chooses to tell about the life he or she has lived, told as completely and honestly as possible" (Atkinson, 1998, p. 8), which allows a degree of insight into lived experiences in the past and present along the course of life. Having a support group for 12 weeks as a solid foundation of mutual trust, Lydia poured out her heart to the first author during the interview. Besides the interview transcript, we also have field notes from the support group as our data. All the original transcripts and coding were in Chinese, and the extractions in this article were translated into English by the authors. "Lydia" is a pseudonym chosen by the participant herself in order to protect her privacy and for confidentiality.

\section{Literature Review}

\subsection{Research on HIV/AIDS Infection and Drug Use in China}

Although there has been a significant reduction in the number of new HIV infections globally, the number of people infected with HIV in China remains high, with an annual rate of increase of about $179.68 \%$ from 2011 to 2017 (China CDC, 2017). By the end of September 2018, the reported number of people living with HIV/AIDS in China was around 850,000; and the reported accumulated number of deaths caused by HIV/AIDS was around 262,000 (China CDC, 2019). Among annually reported new HIV infections, the ratio of men to women decreased from 5:1 in the 1990s to 2.8:1 in 2012 and then increased to 3.4:1 in 2017 (China CDC, 2017). Although more men than women are getting infected with HIV/AIDS, the trend towards the feminization of the illness makes the understanding of women's related experience extremely valuable (Wang, Zhang, Xu, \& Zhang, 2010).

Drug use and the HIV/AIDS epidemic are twinned crises. Official statistics show that the number of registered drug users, those who have been identified by the police due to their drug use, exceeded 2.4 million by the end of 2018, among whom more than half were younger than 35 (National Narcotics Control Commission of China, 2019). Although the vast majority of drug users are men (National Narcotics Control Commission of China, 2016), the number of female drug users has grown considerably in the past few years, especially among women in their adolescence and young adulthood (Liu \& Hsiao, 2018). Studies focusing on the drug use experiences of Chinese female drug users are rare in academia (Liu \& Hsiao, 2018), and hardly any mention women who become infected with HIV/AIDS due to drug use.

Most existing studies regard drug use as a risk factor for HIV infection (Chen et al., 2016), but there are few attempts to adopt an anthropological approach to link the individuals' personal experience with drug use and HIV/AIDS infection together. In general, there is limited information about women infected by HIV/AIDS through drug use while at the same time, we also know very little about the drug using experience among Chinese female AIDS patients. Researching female drug users and women living with HIV/AIDS requires meticulously assessing gender as a crucial factor in understanding how personal experience are related to the persistence of gender inequality and patriarchy in China. A comprehensive literature review by Lin, McElmurry, and Christiansen (2007) found that women were more vulnerable than men to HIV infection, according to eight determinants: biology; society and culture; violence against women; laws; education, knowledge, and skills; poverty; migration; and stigma and discrimination. The existing limited qualitative studies of women living with HIV/AIDS mostly focus on rural women living in the former commercial blood/plasma donation villages which were relatively easier to identify (Wang et al., 2010, 2011; Zhou, 2008). In urban China, particularly in metropolitan cites like Beijing, women living with HIV/AIDS are more scattered geographically and more difficult to find because of stigma, discrimination, and confidentiality. The story of Chinese urban women who are infected by HIV/AIDS through drug use remains consequently largely unknown.

\subsection{Drug Career and Biopolitics: Shifting Research Model}

Drug use is seen as both a public health and social problem globally (South, 2015). Drug users are generally regarded as a vulnerable group who need continuous medical and non-medical treatment to minimize harms inflicted by drug use and eventually achieve abstinence (Bull, Denham, Trevaskes, \& Coomber, 2016; Liu \& Hsiao, 2018). However, both researchers and drug treatment practitioners traditionally hold a negative view towards drug users and regard them as unmotivated individuals who fail to achieve success in both legal and illegal ways (Coombs, 1981).

Starting from the late 1960 s, some scholars tried to view drug users' lives from an alternative perspective. For example, after spending considerable time with drug users in New York, Preble and Cassey (1969) concluded that the individuals were neither immature nor maladjusted, but actively involved in social activities and living meaningful and challenging lives which were similar to the pursuit of a career. Later, Coombs (1981) regarded drug use as a "career" in his research to describe the drug lifestyle, as he thought the drug users' lives, in the social form, is very similar to that of professionals (Liu, Hsiao, \& Kaplan, 2016); therefore, drug use is assumed to express itself in four developmental stagesinitiation, escalation, maintenance, discontinuation and renewal (Coombs, 1981). The adoption of the term "drug career" helps us to view Lydia's drug use experiences from a non-discriminative perspective, and it is a good way to highlight her complexity and agency rather than 
viewing the female drug user as a victim or a bearer of social stigmatization, gender inequality, and patriarchy.

The concept of a drug career echoes Foucault's (1980) ideas of biopolitics, which "operates at two inter connected poles, the regulation of the population as a whole and the disciplines of the individual body," with the purpose of "administration and optimization of the process of life" (Greenhalgh, 2008, p. 6). In the past ten years, especially in the field of medical anthropology, there have been many studies that adopt the theory of biopolitics to examine different social phenomena in China, including the one child policy (Greenhalgh, 2008), dementia (Zhang, 2018), tobacco control (Kohrman, 2007), HIV/AIDS (Hyde, 2007), drug use (Hyde, 2011, 2019) and others. Hyde (2011, 2019) conducted ethnographic research in a community drug treatment center to document how therapy was adopted to turn drug users into good bio-citizens. Hyde (2011, p. 185) argues that "the Chinese addiction case allows for a different framing of therapeutic regimes as forms of biological citizenship and the non-Western ways of pastoral power." Focusing on Lydia's lived experience, at the individual level, this article depicts the process of drug initiation, escalation, maintenance, and finally achieving abstinence; and at the macro level, this article focuses on the institutional and social structure transformation reflected by Lydia's personal experience, especially the social service, treatment, and intervention programs provided in an era of fast growing drug use and increasing population infected with HIV.

Therefore, through diving into Lydia's life history, this case study aims to fill the aforementioned notable gap by exploring an urban Chinese woman's experience with drug use, sex, and HIV infection. Specifically, this study plans to uncover answers to the following questions: (1) How does Lydia develop her body politics in her drug career in the reform era? (2) How is Lydia's drug career related to her social background, intimate relationships, and the experience of living with HIV/AIDS? (3) How does Lydia's story shed light on the flourishing sex industry and the biopolitics of drug and HIV/AIDS management in the reform era in China? Moreover, an analysis of Lydia's profound story would present ideas for building institutions for best practices of gender-specific prevention and intervention programs for other female drug users and women living with HIV/AIDS.

\section{Findings}

\subsection{5-1999: Heroin Initiation}

Lydia's intimate narrative provides valuable insight into the socio-economic dimension of drug initiation. Lydia's life started spinning at the moment when she fell in love with her first boyfriend at the age of 17 . However, her relationship was filled with unbalanced power, in which so called liberal sexual behaviors and traditional gender roles were deeply intertwined with each other. Born with a silver spoon in his mouth and nine years older than Lydia, the boyfriend was "charming and rebellious," and had been recently fired from the police service because he was fighting with his colleague:

It was special with him, even magical. On the second day after we met, he rode a motorcycle and took me to his home, had sex. Afterwards I cried. He was a bit annoyed, "why are you crying?! You are not even bleeding!" Two days later, we did it again, this time I was bleeding. I cried again, I would not [have done] it if I knew that my hymen was intact.

The boyfriend, nicknamed "the earth," in the eyes of Lydia, "rode a motorcycle" like a "white-horse prince." The match fits with the dating culture description "women date up and men date down," which means women often look to date older, wealthier, and taller men (Wang \& Nehring, 2014). Research on virginity loss found that, because of the gender inequality deeply embedded within romantic relationships, many urban Chinese women presented their first experience of sex as containing some element of sexual coercion, but they did not have an opportunity to voice their ambivalent and unpleasant sexual experience (Wang, 2017). This is exactly the case with Lydia. On the one hand, Lydia still treasured her virginity due to the patriarchal tradition; however, on the other hand, she was also enjoying romantic love and yearning for freedom in sexual activities. Lydia cried twice over losing her virginity while her boyfriend mocked her reaction as if she was faking being a virgin. However, she chose to use words like "special" and "magical" to cover the unpleasant emotion and add polish to her first romantic love. It never occurred to her to consider whether the sexual activity was consensual or question her boyfriend's behavior as disrespectful. Lydia had many unsafe sex practices with her boyfriend, as they did not use contraceptives at all and she had to constantly endure his cheating of all kinds. She had five pregnancies and abortions in the next two years. Lydia's family was against pre-marital sex and tried to stop her from seeing her boyfriend. "Leave me alone and I will be responsible for the path I choose," Lydia told her parents. She was determined to stay with him.

The mother of the boyfriend was a chairperson of a state-owned enterprise. In the 1990s, along with the reform of state-owned enterprises, the chairperson's annual income could be dozens or even up to hundreds of times the salary of ordinary citizens in the country. The boyfriend's family was one of the first groups of people grasping at the chance to profit from China's economic development and, with no doubt, belonged to the privileged class. The mother also made use of their governmental connections to "dive into the sea" to set up her own private business alongside the state-owned enterprise, and accumulated a great deal of wealth in a short period of time with all types of legal and illegal (corrupt) methods. Because of her wealth and power, the mother 
was capable of many things including doting on her son with the phrase "living for 'the earth"':

At the moment my boyfriend was fired [from the police station], his mother asked us what we wanted to do. I was a singer, without thinking, I said casually, maybe running a karaoke club. Then within one week, we had one!

If a karaoke club is a dream for a small businessman, fulfilling this dream was too easy for Lydia and her boyfriend. It seems that money was so easy to make, combined with the club scene and sex workers and wealthy clients that rushed in, heroin was just around the corner:

My boyfriend and I were just kids. What did we know about running a business? We just wanted to have fun. When the club opened, xiaojie [sex workers] came along. My boyfriend's mom often told me, "do not chit-chat with those xiaojies and do not wear heavy make-up and mini-skirts; when customers come, they do not know whether you are the boss lady or a xiaojie."

Commercial sex is still illegal in China, but the laws were changed in 1999 so that sex workers and clients could only be arrested "at the scene" (Hong, Zhang, Li, Zhou, \& Guo, 2014). There have been many grey areas that allowed for the flourishing of the underground sex industry ever since the reform era. A karaoke club, at that time, was considered to be one of the places that could have underground commercial sex, or at least, the place where sex workers met and negotiated with their guests (Zheng, 2004). Though sex workers "came along" as "selfemployed without invitation," as Lydia described it, it put her, the boss lady, into the position of a gatekeeper. Gatekeepers are described to be not only intermediaries of the sex trade, but also protectors of female sex workers (Hong et al., 2014). They are supposed to help sex workers avoid legal troubles, gangsters and abusive clients, promote condom use, and prevent substance use. Both Lydia and her boyfriend were too young to play their role as gatekeepers properly. Moreover, they were influenced by the environment that included wealthy clients and sex workers to start using heroin:

Only the wealthy can afford to consume heroin. It is a signal to show that you are rich! The first time I tried heroin was together with my boyfriend. I actually did not think much of it. I got addicted to it in half a year. At that time, the customers were generous. I gave them a discount on their expenses in the club and they would leave some heroin in return.

For Lydia, using heroin was a symbol of being rich and having power. Thrilled with the life of making quick money and easy access to heroin, Lydia never thought of the financial burden to obtain heroin. Living during the day as a college student and at night as a boss lady, Lydia was busy, excited, and stressed, putting on $25 \mathrm{~kg}$ within half a year:

You cannot imagine how fat I was! One night one xiaojie told me, "if you want to lose weight, smoke this." She also said that heroin could be helpful to make me happy and relaxed.

Weight loss and control has been found to be one of the important reasons causing women to start using drugs (Thomas et al., 2018), and it was so convenient for Lydia. Opiates, and heroin in particular, re-emerged in China after the launch of the opening up policy (Huang, Zhang, \& Liu, 2011; Lu, Fang, \& Wang, 2008; Zhang \& Chin, 2015). Heroin entered China through the southern borders, which are adjacent to the Golden Triangle, a traditional opium cultivation and production area (Zhang \& Chin, 2015; Zoccatelli, 2014), and quickly spread to large cities and then throughout the whole country (Lu et al., 2008). Since the drug was expensive and not easy to obtain, using heroin was regarded as a symbol of high socioeconomic status. Thus, heroin shortly became very attractive to wealthy individuals who made quick money during the process of economic reform and, in the late 1990s, heroin became the most popular illegal substance in the country. Moreover, the exchange and sharing of heroin also "fuels social networks and business socializing, with individuals using drugs to secure connections and business acquisitions" (Hyde, 2019, p. 486).

When Lydia graduated from college and got an offer to work at a state-funded theater, she simply declined it because she did not want to "play a small role and could not have fame anyway." For her, being a boss lady was a better option for making quick money and taking a shortcut to success. She was enjoying life as an individual belonging to the wealthy and privileged class because of her boyfriend's family, and she did not mind showing off her wealth. However, because of this choice, she was in an unsafe working environment and surrounded by a high-risk social network, since recreation places like pubs, dance halls, or karaoke clubs were places where drug use was prevalent in the late 1990s in China. Therefore, Lydia started taking heroin as a spontaneous or even unavoidable life event.

\subsection{9-2004: Drug-Centered Life}

The happy time was cut short when Lydia's boyfriend's mother was sentenced to prison for illegal financing. The first wave of corruption in China's reform era was found in the shady world of family and interpersonal connections between socialist planning and a market economy in the 1990s. Osburg (2018) argues that corruption in China shifted to a more "predatory" form after 1992 (Pei, 2006; Sun, 2004; Wedeman, 2012), involving more classic forms of rent seeking, with officials demanding everlarger bribes, dinners, and sexual entertainment for their 
patronage. Some entrepreneurs who made their fortunes in the early reform period cultivated even deeper ties with state officials, which enabled them to commandeer state power to their advantage. This was exactly the game the boyfriend's mother played, and her crackdown was due to the downfall of her high-level official protector. Shortly afterwards, the boyfriend was also caught and sentenced for seven years because of prostitution sheltering and gun possession. At that moment, Lydia had already become heavily addicted to heroin. Without her boyfriend and his mother to rely on, Lydia felt "helpless and hopeless" and could not run the business well by herself. She transferred the karaoke club to a Korean businessman but "still went to the club every night." When her roles shifted from a boss lady to a customer, her comfortable and wealthy life fell into chaos:

I kept on using heroin in the club, together with those xiaojies. Sometimes I accompanied foreign customers and sang them songs, in return I got some tips. In that period, I was getting more and more addicted to heroin.

Lydia quickly spent all her money on heroin use. She had to pay $350 \mathrm{RMB}$ (roughly $\$ 50$ USD) to maintain her daily usage and spent more than 10,000 RMB (roughly $\$ 1,450$ USD) per month, which was the equivalent of the average annual income of Beijingers in the late 1990s and early 2000s. When Lydia was a boss lady, the daily average income of the club could cover her drug use expenses. However, when she was jobless, the drug use expenses became an enormous figure and she could no longer afford it. When the craving for drugs became the center of her life, Lydia often blackmailed the Korean businessman who took over the club for money; moreover, she also asked her relatives, mostly two uncles, for money to maintain her heroin use. Lydia had a falling out with her parents because of her love affair with the boyfriend and that was why she did not ask for money (and could not get any) from her parents. However, her two uncles, both leaders of government-affiliated institutions, loved her and were willing to support her and, therefore, became her sources of money.

\subsubsection{In and Out of Compulsory Treatment}

Lydia was arrested for drug use for the first time shortly after she graduated from college in 1999, and in the following five years, her life was filled with "in and out" of compulsory treatment. The first arrest was caused by a taxi driver robbing her when going out at 2:00 am to buy heroin. The taxi driver was caught, but Lydia was detained too because the police found heroin in her handbag. The first arrest ended after 13 days of detainment, two days less than the standardized term. The second time was just a few days after her release. This time she was sent directly to a re-education through labor (RTL) institution for residential compulsory treat- ment and behavioral rehabilitation, under her parents' special request.

This period of time was also an era when drug use became a fast-growing phenomenon in China. "The epidemiological figures show an exponential increase in injection drug users from a conservative figure of 70,000 in the mid-1990s to estimates of upwards of eight million by 2005" (Reid \& Aitken, 2009, p. 365). Drug use is regarded as a serious deviant behavior in China, leading to police arrest and compulsory treatment (Liu \& Chui, 2018). Realizing the seriousness of drug use, especially during the heroin use epidemic in the 1980s, the Chinese government started to launch various social and legal methods to prohibit drugs and provide treatment to drug users (Zhang, Liu, \& Huang, 2011). Before the end of 2013, drug users who were caught in China would face three different levels of treatment depending on the number of times arrested. For the first arrest, drug users would be registered and detained for 15 days (Zhang \& Chin, 2015). The second arrest would usually lead to a three- to six-month period residential term treatment in a special compulsory detoxification center. On being arrested for the third time, drug users would usually be sent for two years to police-administrated RTL institutions for residential rehabilitation (Larney \& Dolan, 2010; Tang, Zhao, Zhao, \& Cubells, 2006; Zhang \& Chin, 2015).

Lydia relapsed in a few days after she finished her compulsory treatment in 2001. Her parents chose to send her to another residential treatment in the compulsory detoxification center for three months, but she relapsed again on the second day after finishing the treatment. Lydia's parents called the police to take her to RTL institution again when their daughter relapsed after the second treatment. Although Lydia could achieve abstinence during the compulsory treatment, it was very hard to maintain after the treatment finished (Liu \& Hsiao, 2018). A 2005 study by the National Surveillance Center on Drug Abuse reported that $62 \%$ of RTL detainees relapsed within three days of release, with a further $20 \%$ relapsing within 30 days (Hyde, 2019). Community aftercare and re-entry programs were relatively undeveloped in China in the early 2000s.

During these years, whenever Lydia's parents found that she was using drugs again, they chose to call the police and tried to send her back to residential compulsory treatment. Sometimes even the police officers were reluctant to take her in and attempted to persuade her parents: "Lydia is not a bad girl, maybe you can just take her home and watch her closely?" It shows that both the family and national institutions did not have an efficient tool to help drug users achieve and especially maintain abstinence in that era.

\subsubsection{Pregnancy as the "Best Cover"}

Lydia had a brief affair with a married man around 2003, got pregnant, and gave birth to a baby who died quickly after three days. The pregnancy did not bring Lydia back 
to her senses and she did not stop using heroin throughout her pregnancy. Instead, the pregnancy became the "best cover" for Lydia to escape from police arrest and, thus, she easily maintained her drug use.

The pregnancy became a reason for Lydia to ask for money from her two uncles since she "was going to get an abortion." The police officers caught her buying drugs four or five times, but every time, as soon as they realized she was pregnant, she was released immediately. Ironically, she never went to the hospital to have a checkup when she was pregnant. The several times she was examined and knew that the fetus was fine was because the police officers made her get a check-up.

On the day that she gave birth to the baby, she did not want to pay the medical fee in full and instead saved some money for drugs. Discharged on the second day after giving birth, she "carried the baby, took a taxi, and went directly to purchase heroin." Afterwards, she immediately went to find her uncle again to get money. "I just let my uncle see that I gave birth to the baby and that I needed money," Lydia said, "then he gave me several thousand [RMB] although he was very angry." She did not use the money to feed the baby but purchased heroin instead.

Lydia had no knowledge about how to raise a baby and knew nothing about breastfeeding. The baby soon died, lacking the necessary care. At that moment, she was devastated and looked for "one big shot to die, to be with the baby." But after a while, things returned to normal. One year after she lost the baby, she was caught by the police again. The lie "I am still breastfeeding," successfully persuaded the policemen to set her free once again.

\subsection{4 and after: "AIDS Saved Me from the Chaos"}

Lydia was arrested in 2004 and sent to RTL institution again for the third time, and also the last time. As soon as she entered into the institution, she went through mandatory HIV testing. Suffering from acute withdrawal from heroin use, both of Lydia's legs were swollen and she barely could walk. She contracted tinea capitis and started to lose her hair. She kept wondering what was wrong with her, but the guard did not tell her. She found out one day when her mother came to visit:

My mom hugged me, told me it was AIDS. I jumped from her arms, tears were falling down....I did not say anything, faced the wall, tears kept falling.

Lydia used to joke that "maybe [she] got AIDS," and lied about AIDS once for money; however, it was still pretty hard for her to accept reality at that very first moment:

I thought I only could live two or three years. In the clinic [of the RTL institution], there was a doctor who came to see me from time to time. Every time she would say, "this is the girl whose CD4 [cluster of dif- ferentiation 4, a glycoprotein found on the surface of immune cells such as $\mathrm{T}$ helper cells, monocytes, macrophages, and dendritic cells] is dropping rapidly." I did not know what that meant, but I thought that I was going to die soon.

At that time, Lydia had a serious complication, peptic ulcer disease, and she was in pain constantly and felt like she was living in hell. The institution's clinic had limited medical resources which could neither provide her with enough treatment nor ease her pain. Living in agony and fearing the life-threatening illness, Lydia, for the first time, felt that she could no longer live like that and decided: "I have to quit!" Also, a new policy on HIV/AIDS, "Four Free and One Care," was issued on World AIDS Day 1 December 2003, which provided AIDS patients with free antiretroviral treatment, voluntary counseling and testing, prevention of mother-to-child transmission, schooling for AIDS orphans, and social assistance for HIV patients. If Lydia continued staying in the RTL institution, she would not be eligible to receive the free treatment benefits. Witnessing her serious complications and suffering, Lydia's parents decided to apply for early release for medical reasons in order to help her obtain antiretroviral treatment and other necessary treatments for different types of opportunist infections. She was then sent from the RTL institution directly to a hospital. After several weeks of hospitalization and treatments, her CD4 levels increased and she recovered from the opportunist infections. Looking back, Lydia said that she "never wants to go through that miserable experience again" and talked about her understanding of AIDS:

Many people complained about the unfairness of God when they were infected, however, I am grateful for the disease....Someone can live with it for more than 30 years. Maybe doctors will find a cure soon. I am grateful for this disease, otherwise I cannot imagine how I could have quit the thing [heroin].

Hou (2018) adopted a concept from Chinese Taoist philosophy, "living in the face of death" (xiang si er sheng), to describe the optimism and courage of people living with HIV/AIDS, who embrace the illness as the gift of life and live in the moment. Hyde (2017, p. 173) pointed out that "to function as a caring citizen in market-socialist China is to foster one's own individuality by balancing caring for the self and caring for the public good."

Lydia's transformation is related to three levels. First is the individual level-she was determined to utilize "technologies of the self-permitted individuals to effect change by their own means so as to transform themselves in thought, conduct, and ways of being in the world" (Foucault, 1983, p. 238). She started to regard HIV/AIDS as "saving her from the chaos" and giving her a chance to live a new life.

Secondly, on the narrative level, it's interesting to notice that Lydia often used the third person to address 
herself as the "drug user" when talking about her "drugcentered" life. In her description, "the drug user" usually was "smart, sweet-talking, outgoing, and good at building relationships and getting things done" though sometimes they would engage in "petty theft" and "compensated dating" under "devastating situations." In her narrative, "the drug user" became an absolute otherness, different from her current self and living in the eternal past.

Thirdly, on the interpersonal level, she became a volunteer for an AIDS rights group, joined an art troupe to perform in colleges and communities to raise awareness of HIV/AIDS among the general public and, once again, put her singing talent to good use. Her actions and involvement as a person living with HIV who speaks up has become the most powerful resource in breaking the silence on HIV, creating awareness and supporting the importance of prevention.

\section{Discussion and Conclusion}

The story of Lydia is extraordinary, and her personal story links sex, drug, and HIV/AIDS together to shed light on the expansion of the sex industry and policy changes in relation to drug use and HIV/AIDS in the reform era. Her story becomes an allegory about the rise and fall of an ambitious urban young woman in pursuit of success, desire, and wealth in reform China. The illness becomes a wake-up call and turning point for her to exchange the dysfunctional self for the "more regulated, familial, selfactualized, malleable, and responsible self" (Hyde, 2017, p. 71) to become a good bio-citizen in the era of the HIV epidemic.

Romantic love became the entry point for Lydia giving up a predictable, stable life of being a musician, marching instead into a life of short-cuts to make quick money and for success. The relationship was filled with unbalanced power: She was never an equal partner to her boyfriend, her body was objectified, and lack of safe sex practices often put her in rather vulnerable positions. The roller coaster of wealth and success was so enticing that young women like Lydia chose to give up the "iron bowl" (stable job in the public sector) and eat "spring rice of youth" (Hanser, 2005). However, the anti-corruption movement in the late 1990s rushed in, causing the imprisonment of her boyfriends' mother, their financial backbone, which therefore cut her sweet dream short as she became dependent on drug use.

Lydia's story of a drug-centered life happened in the period of time of the flourishing of the sex industry in urban cities and injection drug use (syringe sharing) was the main mode of HIV infection. According to the statistics, $63.7 \%$ of total reported HIV/AIDS cases were contracted through injecting drug use by the end of 2002; and in Beijing, at least $5 \%$ of drug users were infected with HIV/AIDS (Shen, Liu, Han \& Zhang, 2004). Therefore, drug treatment became a very important method to control or reduce the spread of HIV/AIDS. Lydia's story un- doubtedly points out the inadequacy of compulsory institutional drug treatment in that era. In the end, her willingness to quit the drug was much more effective than the numerous treatments she endured. The focus of the compulsory institutional drug treatment under the RTL system was mainly behavioral rehabilitation, therefore, medical services to help drug users ease their withdrawal symptoms were generally limited. Together with the lack of community-based reentry programs, Lydia relapsed very shortly after treatment for several years. Similar to all the other times, "a stint in compulsory detoxification rarely results in a former drug addict giving up drugs" (Pisani \& Zhang, 2017, p. 7).

"Four Free and One Care" was a policy breakthrough in China's history of dealing with HIV/AIDS. Lydia ended her drug treatment earlier so she could enjoy the free HIV treatment, and the minimum living security she received from the residents' committee helped her get through her daily life. Along with the issuing of Regulations on AIDS Prevention and Treatment by the state council in 2006, the anti-drug law of China in 2008 , and the termination of the RTL system at the end of 2013, the Chinese government has gradually improved drug treatment services and combined the drug treatment system with the prevention of the epidemic of HIV/AIDS. The revised compulsory institutional drug treatment focuses more on detoxification rather than behavioral rehabilitation, and now encompasses different methods to help drug users achieve and maintain abstinence. Moreover, community-based drug treatment has now been introduced as an alternative approach alongside institutional treatment in China (Lu et al., 2008; Zhang \& Chin, 2015). These community-based drug treatment programs include both medical ones such as methadone maintenance treatment and nonmedical ones such as social work intervention (Liu \& Chui, 2018). Thus, in China, individuals now, compared to the time when Lydia's story happened, can receive better treatment and aftercare services in communities to maintain abstinence.

The information demonstrates that improving drug treatment services can be one of many ways to prevent the spread of HIV/AIDS. HIV prevalence among drug users nationwide has continued to decline in China from $30.3 \%$ in 1999 to $10.9 \%$ in 2011 (Wu, Wand, Detels, \& Bulterys, 2014), and then rapidly to $3.4 \%$ in 2017 (China CDC, 2019). Strong governmental commitment, solid public health infrastructure, and available social assistance systems build up a foundation for drug treatment and HIV/AIDS prevention. However, more active local NGOs that get involved to provide education programs and social support interventions for women living with HIV/AIDS and drug users are still essential.

\section{Acknowledgments}

Publication of this article is supported by the International Joint Research Project of the Faculty of Educa- 
tion, Beijing Normal University, the Harvard-Yenching Institute Visiting Scholarship, the National Social Science Fund of the People's Republic of China (19BSH029), and Jiangsu Provincial Social Sciences Research Key Project, the People's Republic of China (2018SJZDI119). We would like to thank Ms. Guo Ting for her assistance in collecting and transcribing the data.

\section{Conflict of Interests}

The authors declare no conflict of interests.

\section{References}

Atkinson, R. (1998). The life story interview. Thousand Oaks, CA: Sage.

Bull, M., Denham, G., Trevaskes, S., \& Coomber, R. (2016). From punishment to pragmatism: Sharing the burden of reducing drug-related harm. The Chinese Journal of Comparative Law, 4, 300-316.

Chen, B., Zhu, Y., Guo, R., Ding, S., Zhang, Z., Cai, H., . . . Wen, Y. (2016). HIV/AIDS-related knowledge awareness and risk behaviors among injection drug users in Maanshan, China: A cross-sectional study. BMC Public Health, 16, 97-105.

China CDC. (2017). National AIDS epidemic statistics for the first quarter of 2017. Beijing: Government of the People's Republic of China. Retrieved from http:// www.chain.net.cn/info_view/12730

China CDC. (2019). Analysis of the number of people living with AIDS, new infections, number of deaths and transmission paths in China in 2018. Beijing: Government of the People's Republic of China. Retrieved from http://www.chyxx.com/industry/ 201808/665644.html

Coombs, R. H. (1981). Drug abuse as career. Journal of Drug Issues, 11(4), 369-387.

Foucault, M. (1980). The history of sexuality (Vol. 1). New York, NY: Pantheon.

Foucault, M. (1983). The subject and power. In H. L. Dreyfus \& P. Rabinow (Eds.), Beyond structuralism and hermeneutics (pp. 208-226). Chicago, IL: University of Chicago Press.

Greenhalgh, S. (2008). Just one child: Science and policy in Deng's China. Los Angeles, CA: University of California Press.

Hanser, A. (2005). The gendered rice bowl: The sexual politics of service work in urban China. Gender \& Society, 19, 581-600.

Hong, Y., Zhang, C., Li, X., Zhou, Y., \& Guo, W. (2014). Female sex workers and their gatekeepers in China: Implications for HIV/STI prevention. Qualitative Health Research, 24(10), 1431-1439.

Hou, R. (2018). The self-reconstruction of people living with HIV/AIDS [in Chinese]. Wuhan: Huazhong University of Science and Technology Press.

Huang, K., Zhang, L., \& Liu, J. (2011). Drug problems in contemporary China: A profile of Chinese drug users in a metropolitan area. International Journal of Drug Policy, 22(2), 128-132.

Hyde, S. T. (2007). Eating spring rice: The cultural politics of AIDS in southwest China. Berkeley, CA: University of California Press.

Hyde, S. T. (2011). Migrations in humanistic therapy: Turning drug users into patients and patients into healthy citizens in Southwest China. Body \& Society, 17(2/3), 183-204.

Hyde, S. T. (2017). 'Spending my own money, harming my own body': Addiction care in a Chinese therapeutic community. Medical Anthropology, 36(1), 61-76.

Hyde, S. T. (2019). Beyond China's drug century: Yunnan's first therapeutic community and narratives of drug treatment and mental health care. Transcultural Psychiatry, 56(3), 471-490.

Kohrman, M. (2007). Depoliticizing tobacco's exceptionality: Male sociality, death and memory-making among Chinese cigarette smokers. China Journal, 58, 85-109.

Larney, S., \& Dolan, K. (2010). Compulsory detoxification is a major challenge to harm reduction in China. International Journal of Drug Policy, 21, 165-166.

Lin, K., McElmurry, J. B., \& Christiansen, C. (2007). Women and HIV/AIDS in China: Gender and vulnerability. Health Care for Women International, 28, 680-699.

Liu, L., \& Chui, W. H. (2018). Rehabilitation policy for drug addicted offenders in China: Current trends, patterns, and practice implications. Asia Pacific Journal of Social Work and Development, 28(3), 192-204.

Liu, L., \& Hsiao, S. C. (2018). Chinese female drug users' experiences and attitudes with institutional drug treatment. International Journal of Offender Therapy and Comparative Criminology, 62(13), 4221-4235.

Liu, L., Hsiao, S. C., \& Kaplan, C. (2016). Drug initiation of female detainees in a compulsory drug treatment institution in China. Journal of Psychoactive Drugs, 48(5), 393-401.

Lu, L., Fang, Y., \& Wang, X. (2008). Drug abuse in China: Past, present and future. Cellular and Molecular Neurobiology, 28, 479-490.

National Narcotics Control Commission of China. (2016). Annual report on drug-using situation in China 2015. Beijing: Ministry of Public Security, People's Republic of China.

National Narcotics Control Commission of China. (2019). Annual report on drug-using situation in China 2018. Beijing: Ministry of Public Security, People's Republic of China.

Osburg, J. (2018). Make business personal: Corruption, anti-corruption, and elite network in post-Mao China. Current Anthropology, 59(S18), S149-S159.

Pei, M. (2006). China's trapped transition: The limits of developmental autocracy. Cambridge, MA: Harvard University Press.

Pisani, E., \& Zhang, N. (2017). AIDS comes to China. In Z. $\mathrm{Wu}$ (Ed.), HIV/AIDS in China: Beyond the numbers (pp. 
1-8). Beijing and Singapore: People's Medical Publishing House and Springer.

Preble, E., \& Cassey, J. J. (1969). Taking care of business: The heroin user's life on the street. The International Journal of the Addictions, 4, 1-24.

Reid, G., \& Aitken, C. (2009). Advocacy for harm reduction in China: A new era dawns. International Journal of Drug Policy, 20(4), 365-370.

Shen, J., Liu, K., Han, M., \& Zhang, F. (2004). The China HIV/AIDS epidemic and current response. In J. P. Narain (Ed.), AIDS in Asia: The challenge ahead (pp. 171-199). London: Sage.

South, N. (Ed.). (2015). Drugs: Cultures, controls and everyday life. London: Sage.

Sun, Y. (2004). Corruption and market in contemporary China. Ithaca, NY: Cornell University Press.

Tang, Y. L., Zhao, D., Zhao, C., \& Cubells, J. F. (2006). Opiate addiction in China: Current situation and treatments. Addiction, 101, 657-665.

Thomas, R. L., Kelly, A. B., Chan, G. C. K., Hides, L. M., Quinn, C. A., Kavanagh, D. J., \& Williams, J. W. (2018). An examination of gender differences in the association of adolescent substance use with eating and weight loss attitudes. Substance Use \& Misuse, 53(13), 2125-2131.

Wang, X. (2017). Dating, gender, and violence in urban China. London: Routledge.

Wang, X., \& Nehring, D. (2014). Individualization as an ambition: Mapping the dating landscape in Beijing. Modern China, 40, 578-604.

Wang, X., Zhang, X., Xu, Y., \& Zhang, Y. (2010). Women, poverty, and the epidemic in China: Case studies on rural people living with HIV/AIDS. IIIness, Crisis and Loss, 18(2), 129-146.

Wang, X., Zhang, X., Xu, Y., \& Zhang, Y. (2011). Health service access for rural people living with HIV/AIDS in China: A critical evaluation. Journal of Sociology and Social Welfare, 38(4), 77-100.

Wedeman, A. (2012). Double paradox: Rapid growth and rising corruption in China. Ithaca, NY: Cornell University Press.

Wu, Z., Wand, Y., Detels, R., \& Bulterys, M. (2014). Towards ending HIV/AIDS among drug users in China. Addiction, 110(S1), S1-S3.

Zhang, L., Liu, J., \& Huang, K. (2011). The role of criminal justice system in treating drug abusers: The Chinese experience. Journal of Substance Abuse Treatment, 41, 45-54.

Zhang, S. X., \& Chin, L. (2015). A people's war: China's struggle to contain its illicit drug problem. Washington, DC: The Brookings Institution. Retrieved from https://www.brookings.edu/wp-content/uploads/ 2016/07/A-Peoples-War-final.pdf

Zhang, Y. (2018). Governing dementia: A historical investigation of the power of states and professionals in the conceptualization of dementia in China. Culture, Medicine, and Psychiatry, 42, 862-892.

Zheng, T. (2004). From peasant women to bar hostesses: Gender and modernity in post-Mao Dalian. In A. M. Gaetano \& T. Jacka (Eds.), On the move: Women and rural-to-urban migration in contemporary China (pp. 80-108). New York, NY: Columbia University Press.

Zhou, R. Y. (2008). Endangered womanhood: Women's experience with HIV/AIDS in China. Qualitative Health Research, 18(8), 1115-1121.

Zoccatelli, G. (2014). "It was fun, it was dangerous": Heroin, young urbanites and opening reforms in China's borderlands. International Journal of Drug Policy, 25, 762-768.

\section{About the Authors}

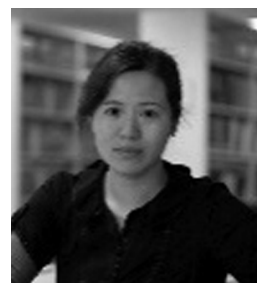

Xiying Wang $(\mathrm{PhD})$ is a Professor at the Institute for Education Theories, Faculty of Education, at Beijing Normal University. She is also a Harvard-Yenching Institute Visiting Scholar 2019-2020. Her research interests include gender-based violence, sex education, school bullying, women living with HIV/AIDs, sociology education, youth studies, gender studies, and qualitative research methods. Her recent book Gender, Dating and Violence in Urban China was published by Routledge in 2017 (hardcover) and in 2019 (paperback).

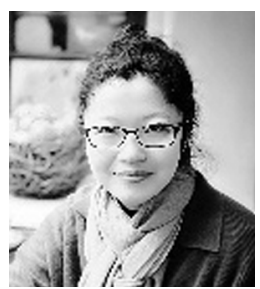

Liu Liu (PhD) is an Associate Professor at School of Social and Behavioral Sciences, Nanjing University. She received her PhD degree from the University of Hong Kong and was a visiting scholar in Suzanne Dworak-Peck School of Social Work, University of Southern California, between 2013 and 2014. Dr. Liu's research focuses on substance abuse, drug-related offending, juvenile delinquency, school bullying, and treatment of female offenders. She published widely on these topics, and especially in the area of substance abuse. 